\title{
Causes of accidents at work in the opinions of public sector forestry employees in Poland
}

\author{
Agnieszka Buczaj ${ }^{1, A-B, D, F} \oplus$, Anna Pecyna ${ }^{1, A-B, D, F}{ }^{\circ}$, Stanisław Lachowski ${ }^{2, C} \oplus$, Piotr Choina ${ }^{3, B-C, E \oplus}$, \\ Małgorzata Goździewska ${ }^{3, B, E-F \oplus}$ \\ ${ }^{1}$ University of Life Sciences in Lublin, Poland \\ ${ }^{2}$ Maria Curie-Sklodowska University, Lublin, Poland \\ ${ }^{3}$ Department of Medical Anthropology, Institute of Rural Health, Lublin, Poland \\ A - Research concept and design, B - Collection and/or assembly of data, C - Data analysis and interpretation, \\ $D$ - Writing the article, $E$ - Critical revision of the article, $F$ - Final approval of article
}

Buczaj A, Pecyna A, Lachowski S, Choina P, Goździewska M. Causes of accidents at work in the opinions of public sector forestry employees in Poland. Ann Agric Environ Med. 2020; 27(1): 6-14. doi: 10.26444/aaem/112020

The article continues the presentation of results which have been published previously in more detail of a study conducted by the University of Natural Sciences, Institute of Rural Health, and Maria Curie-Skłodowska University in Lublin, Poland [1].

\begin{abstract}
Objective. The aim of the study was recognition of opinions of forestry employees concerning causes of accidents in forestry, and evaluation of which of the selected demographic characteristics of forestry employees are associated with their opinions concerning causes of occupational accidents. An attempt was also undertaken to answer the question whether there is any relationship between the opinions of forestry employees pertaining to the causes of accidents at work, and observance of the OSH principles concerning the use of protection measures.

Materials and method. The survey included 135 forestry employees and conducted by using an author-constructed questionnaire containing items which primarily concerning the causes of accidents at work and the protection measures applied. The opinions of forestry employees pertaining to the causes of accidents were analyzed according to independent variables, such as: workplace, period of employment, age, education level, and an index of the level of the respondents' concern about OSH (index of the use of personal protection measures by the respondents). The significance of differences between the subgroups selected according to the above-mentioned variables was assessed using the chi-square test.

Results. Forestry employees most frequently indicated such causes of accidents as the lack of e use of protection equipment (63.7\%), bravado and neglecting hazards (63\%), as well as entering or staying in a danger zone during tree felling (56.3\%). Nearly a half of the respondents (48.1\%) mentioned as the cause of accidents the improper and self-willed behaviour of an employee. The respondents additionally mentioned being taken by surprise by an unexpected event (40\%), and the inadequate state of machinery, equipment, and vehicles (36.3\%).

Conclusions. Based on the results of the study concerning the causes of accidents in forestry, it was found that the examined forestry employees show high awareness and knowledge concerning the causes of occupational accidents in forestry. The greatest differences in the way of perceiving the causes of accidents and hazards were observed according to the respondents' period of employment and age. In addition, a relationship was observed between indication by the respondents of specified causes of accidents, and the scope of their use of protection measures.
\end{abstract}

\section{Key words}

forestry, occupational accidents, accident rates in forestry

\section{INTRODUCTION}

The problem of accident rates in forestry has been the object of study by many researchers. The vast majority of studies of this problem in Polish forestry were conducted during the period before privatisation $[2,3,4,5,6,7,8]$. The process of privatisation carried out in forestry during the 1990s consisted in the liquidation of workers' positions burdened with a high accident risk and occurrence of occupational diseases (vibration disease, hearing loss). Instead, these work activities, i.e. timber harvesting, extraction and transport of timber, which are indispensable for completion of the assumed plan for the acquisition of raw material, began to be outsourced to private sector companies $[9,10,11]$. According to Grzywiński et al. [9, 12], relegation of the

Address for correspondence: Anna Pecyna, University of Life Sciences in Lublin, Poland

E-mail: anna.pecyna@up.lublin.pl

Received: 05.07.2019; accepted: 13.08.2019; first published: 05.09.2019 performance of hazardous work activities within the scope of functioning of the State Forests to external entities did not result in any decrease in accident rates, but rather caused an increase in the indices of the frequency and severity of accidents. Nowacka and Moskalik [10] reported that at present machinery teams and forestry labourers are rare on the State Forests National Forest Holding (PGLLP), because they have very little executive potential. In the PGLLP there is practically no such work position as a feller which, considering the occurring risk, is the most dangerous workplace, and definitely exerts an effect on the frequency of accident events in terms of sectors of work. Before the process of privatisation of Polish forestry, accidents during timber harvesting constituted $40-55 \%$ of all events, whereas during the period 2004-2011, the structure of accidents was as follows: $27-34 \%$ of all accidents happened during timber harvesting, 3-7\% - transport of timber, and 63-69\% - while performing the remaining work activities (i.e. activities other than harvesting and transport). Despite the outsourcing of 
especially dangerous jobs and work operations to external entities, the level of risk associated with the sector of timber harvesting is very high (approximately $30 \%$ of occupational accidents), and accident rates remain on a high level [10]. At present, the highest accident risk occurring in the PGLLP is connected with collection and dispatching of wood, tree stand evaluation, determination of tree cuts, as well as organization and supervision of tree felling. These tasks are performed by the largest occupational group in the State Forests, i.e. forester and forest ranger [10, 13].

According to data of the Central Statistical Office (GUS), in recent years the number of accidents in forestry remained on a similar, high level [14]. In 2017, in the whole sector of forestry, there occurred 439 accidents, including 11 that were fatal, 5 severe and 423 light accidents. In the forest economy and the remaining forest activity, excluding the acquisition of forest products, there occurred 275 accidents - 26 during timber harvesting, and 138 accidents during service activity associated with forestry. In 2017, in the private sector, there occurred 156 occupational accidents, whereas in the public sector - 283 [14]. However, it should be mentioned that accident statistics by the GUS concerning the private sector of forestry cover entities which employ 9 or more workers. The statistics do not include smaller enterprises and persons who are selfemployed and mainly perform tasks associated with timber harvesting. The actual number of accidents in this sector may also be higher for another reason, namely, as reported by Grzywiński [15], a considerable percentage of lumberjacks are private farmers (in some regions this may even be $25 \%$ ), accidents among them are registered in the Agricultural Social Insurance Fund (KRUS) and are not included in the GUS statistics, which additionally hinders the obtaining of actual data concerning accident rates in the private sector of forestry.

In the public sector, accidents most frequently occurred among workers occupying labourer positions (65.9\%), most often lumberjacks, chainsaw operators, and forestry labourers (13.7\%), whereas the smallest number of victims of accidents was observed among office employees (5.3\%). Among field forest administration, the greatest number of accidents occurred at the workplaces of a forester and deputy forester (22.7\%) [9]. In 2010-2017, the most frequently recognized cause of occupational accident was invariably the incorrect behaviour of an employee. In 2017, among the causes of accidents at work in forestry, according to the events causing injuries to the victim, there dominated 'being hit by an object in motion', 'collision with/striking a stationary object, and 'contact with an object that is sharp, rough and coarse'. These data were confirmed by Grzywiński et al. [9] who reported that the most frequent events directly causing an accident and constituting $5 \%$ of all occurring accidents were: careless treading, slipping, stumbling or the fall of a person. Accidents most often happened when the employee moved, including (more than 51\% in 2017) while walking, running, climbing, descending, etc. These are everyday activities connected with the performance of the basic duties of foresters and forest rangers whose work mainly consists in moving around in the field. Hence, there also occurs a high risk of injuries to the lower extremities due to slipping or falling [9]. The subsequent activity performed by the victims at the moment of accident (approx. 22\% of all accidents in 2017) is work with the use of manual tools [14].

Considering the parts of body which are injured, there most frequently occurred injuries to the lower extremities
(46\%) and upper extremities (24.7\%). This is related with the direct cause of an accident, and in more than $1 / 3$ of cases these were careless treading, stumbling or slipping and, in consequence, a fall. In $13.3 \%$ of cases, the victims sustained injuries to the trunk. Every tenth accident caused injuries to the head which, including eye injuries, constituted $14.6 \%$ [14].

An increase was observed in the number of traffic accidents resulting in severe body injuries requiring a long-lasting period of convalescence, which resulted in an increase in the index of severity of accidents [14].

The application and observance of the $\mathrm{OSH}$ principles plays an important role while performing work in forestry. A systematic improvement of the awareness of employees by means of proper trainings in the observance of OSH principles and regulations, hazards occurring at workplaces, information concerning the methods of minimization of the risk of occurrence of accidents caused mainly by human mistakes, exerts a considerable effect on the reduction in the number of occupational accidents $[11,16]$. According to Burzyńska-Jędrzejczak and Kaźmierczak [13], the shortening of the periods between trainings should also be taken into consideration, not always using the maximum 5 -year periods. In turn, in order to reduce or avoid muscle injuries (such as tension and twisting) the employees should be provided with proper ergonomic training [16].

Gellerstedt [17] mentioned ergonomic factors which exert an effect on the occurrence of accident risk at work in forestry, e.g. inappropriate psychosocial environment, slight appreciation of the work being performed, low selfesteem, lack of work experience, cigarette smoking, poor physical condition and past diseases concerning muscles and joints. The effect of these factors may be eliminated by the provision of education and trainings, as well as proper work organization [18].

\section{OBJECTIVE}

The objective of the study was recognition of the opinions of forestry employees concerning the causes of accidents in forestry, and evaluation of which of the selected demographic characteristics of forestry employees are associated with their opinions concerning the causes of occupational accidents. In addition, an attempt was undertaken to provide an answer to the question whether there is any relationship between the opinions of forestry employees concerning the causes of accidents at work, and the observance of the OSH principles with respect to the use of protection measures. The adopted goal was attained by carrying out an anonymous survey in a group of 135 forestry employees.

\section{MATERIALS AND METHOD}

Recognition of accident causes by forestry workers and their evaluation according to demographic data. The survey was conducted using an author-constructed questionnaire designed by a team of specialists in the area of ergonomics, $\mathrm{OSH}$, and sociology within the research project of the University of Natural Sciences in association with the Institute of Rural Health and the Marie-Curie University in Lublin. The questionnaire contained items pertaining to hazards occurring at workplaces in forestry, questions about 
the respondents' opinions concerning causes of occupational accidents, and the protection measures applied (a detailed description of the research instrument in: Pecyna et al. [1]).

The study was conducted during the period 2017-2018 among employees of the State Forests in the Lublin Province of eastern Poland, and covered a group of 135 forestry employees holding the positions of a forester (59), forest ranger (54) and office employee (22). A half of the respondents (49.6\%) were aged $31-50,36$ were aged 51 and over, and 32 respondents were aged $18-30$. As many as $37 \%$ of the respondents declared the shortest period of employment (less than 10 years), $43 \%$ of respondents - the longest period of employment (more than 21 years), whereas $20 \%$ had the period of employment from 11-20 years. As many as 60 forest employees had university education, 72 had secondary school education, and 3 persons had vocational education; no one in the examined group had primary school education.

The collected material was analyzed using software SPSS 24. Basic descriptive statistics was applied - compilations of numbers and percentages of individual variables. The opinions of forestry employees concerning the causes of accidents were analyzed according to independent variables, such as: workplace, period of employment, age and education level, as well as an index of the level of the respondents' concern about OSH (index of the use of personal protection measures). The significance of differences between subgroups selected according to above-mentioned variables was assessed by means of the chi-square test.

Index of workers' concern about safety at work. In order to determine the relationship between the opinions of forestry employees concerning the causes of occupational accidents and the observance of the OSH principles with respect to the use of protection measures, an index of the level of the respondents' concern about OSH was developed. The examined forestry employees were asked about the use of the protection measures at work; 9 types of protection measures were mentioned which are recommended for use by forestry employees. Taking into consideration the specificity of the investigated workplaces in forestry, weights were ascribed to individual types of protections considering their importance for safety during the performance of work. The weights were ascribed based on evaluations performed by 7 judges (specialists in OSH in forestry). The evaluations were performed according to a 5-point scale where 1 was lack of effect on work safety, and 5 - a very high effect on work safety. Each type of protection measure was evaluated by the judges separately for 3 workplaces: 1) forester, 2) forest ranger, 3) office employee. The arithmetic mean was calculated for each type of protection measure separately for each workplace (Tab. 1). Weights ascribed to individual protection measures for the workplaces of forester and forest ranger were very similar. The highest weights were given to the use of work footwear (5.0 and 4.86, respectively), while the lowest - to the use of dust masks (2.14 and 2.43, respectively). Completely different weights were ascribed to protection measures at office workplaces. The use of dust masks obtained the lowest weight (1 - lack of importance for OSH), whereas the highest - to the use of corrective glasses (4.57).

Based on respondents' opinions concerning the use of the above-mentioned protection measures an index of worker's concern about safety at work was developed, which is the sum of weights of individual types of protection. Taking into
Table 1. Assessment of the use of personal protection measures for OSH while performing work according to workplaces

\begin{tabular}{lccc}
\hline \multirow{2}{*}{ Type of protection } & \multicolumn{3}{c}{ Workplace } \\
\cline { 2 - 4 } & Forester & $\begin{array}{c}\text { Forest } \\
\text { ranger }\end{array}$ & $\begin{array}{c}\text { Office } \\
\text { employee }\end{array}$ \\
\hline work footwear & 5.00 & 4.86 & 1.43 \\
\hline work wear & 4.86 & 4.71 & 1.43 \\
\hline gloves & 4.00 & 3.86 & 1.43 \\
\hline dust masks & 2.14 & 2.43 & 1.00 \\
\hline protective helmets & 4.71 & 4.86 & 1.29 \\
\hline protective ear-muffs & 3.14 & 3.29 & 1.00 \\
\hline goggles & 3.43 & 3.57 & 1.57 \\
\hline warning vest & 4.71 & 4.71 & 1.71 \\
\hline corrective glasses & 3.71 & 3.57 & 4.57 \\
\hline Sum - maximum value of concern about $\mathbf{\text { OSH }}$ & $\mathbf{3 5 . 7 1}$ & $\mathbf{3 5 . 8 6}$ & $\mathbf{1 5 . 4 3}$ \\
\hline
\end{tabular}

account the specificity of individual workplaces (different needs with respect to the use of protection measures) standardization was performed according to the following formula: Standardized index of concern about OSH = (index of concern about $\mathrm{OSH} /$ maximum value of concern about $\mathrm{OSH}){ }^{\star} 100$.

Each respondent obtained a standardized value of the index of a worker's concern about OSH according to the scale $0-73$. Based on the division of a distribution by percentiles 'Standardized index of concern about OSH', it was assumed that the values of this index remaining within 0-27 mean a low level of concern about OSH, values from 27.1-40 mediocre low level of concern about OSH, values over 40 - a high low level of concern about OSH.

While adopting the above-presented criteria, the examined forestry employees were divided into 3 groups with similar numbers: respondents with a low level of concern about OSH (32.6\%), respondents with a mediocre low level of concern about OSH (31.9\%), respondents with a high low level of concern about OSH (48-35.5\%)

\section{RESULTS}

Recognition of accident causes by forestry workers and their evaluation according to demographic data. At workplaces in forestry there occur many hazards which may be the cause of accidents. The respondents were presented with 16 typical causes of accidents occurring in forestry and were asked to indicate those which occur at their workplaces. From among these hazards (Graph 1), the respondents most often reported human factors, such as: lack of use of protective measures (63.7\%), bravado and neglect of risks (63\%), staying in the danger zone during tree felling or entering such a zone $(56.3 \%)$. Nearly a half of the respondents (48.1\%), as a cause of accident, indicated improper, selfwilled behaviour of the worker. In addition, the respondents stated to being taken by surprise by an unexpected event (40\%), and an inadequate state of machinery, equipment, and vehicles $(36.3 \%)$. Nearly $1 / 3$ of the respondents $(31.9 \%)$ reported the lack of observance of the regulations concerning especially dangerous work activities as the cause of accidents at work in forestry. According to $24.4 \%$ of respondents, an inappropriately prepared and organized workplace may also 


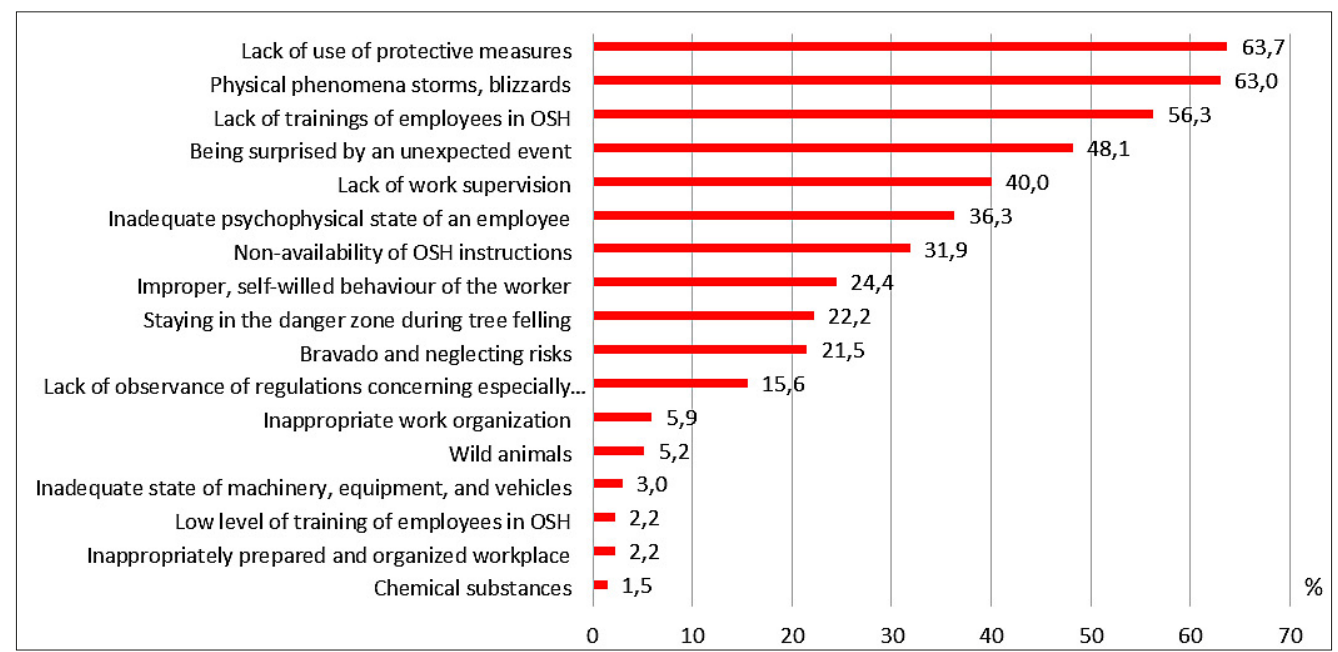

Figure 1. Causes of accidents at a workplace indicated by the employees (\%)

cause an accident, and $22.2 \%$ reported inappropriate work organization. Physical phenomena (storms, blizzards) were indicated by $15.6 \%$ of respondents. The most rarely reported causes of accident were: lack of work supervision (5.9\%), improper use of firearms (5.9\%), and lack of trainings of employees in $\mathrm{OSH}$ or low level of training (5.2\%). A small number of respondents mentioned as the cause of accidents, contact with wild animals (3\%) and chemical substances (2.2\%). Only $1.5 \%$ of respondents indicated the fact that the non-availability of instructions may result in the occurrence of an occupational accident.

While seeking factors related with the perception of the causes of accidents at a workplace by forestry employees, an hypothesis was adopted that their way of perception depended on such respondents' characteristics as: period of employment, age and education, position held and scope of the use of protective measures at work.

The conducted analyses show that the greatest differences in the way of perceiving risk were observed according to the respondents' period of employment and age (Tab. 2, 3).

The analyses performed demonstrated that the majority of the causes of accidents indicated by the respondents were not related with the period of employment. Statistically significant differences $(\mathrm{p}<0.05)$ in the subgroups divided according to the period of employment were found with respect to such causes of accidents as: lack of use of protective measures, improper, self-willed behaviour of the employee, staying in a danger zone during tree felling or entering such a zone, and lack of work surveillance.

Accidents involved $81.5 \%$ of forestry employees with the period of employment of 11-20 years, and a considerably lower percentage of respondents with the period of employment up to 10 years (64\%). Improper, self-willed behaviour of the employee as the cause of accident, to a similar extent, was perceived by respondents with the shortest period of employment (up to 10 years $-54.0 \%$ of this group), and employees with the longest period of employment (more than 21 years $-51.7 \%)$. Nearly $2 / 3$ of the respondents $(62.7 \%)$ who had been employed in forestry for more than 21 years, and a slightly lower percentage with the period of employment up to 10 years (58\%), as the causes of accidents, staying in the danger zone during tree felling or staying in such a zone, and lack of work surveillance, were stated. Nearly $1 / 5$ of employees with the period of employment of 11-20 years mentioned that accidents were caused by the lack of work supervision (18.5\%), whereas in the groups with the longest and the shortest work experience, this problem was reported by only single persons ( $3 \%$ and $2 \%$, respectively; statistically significant differences, $\mathrm{p}<0.05)$.

Significant differences in the perception of accidents by forestry employees were also observed according to age. Statistically significant differences $(\mathrm{p}<0.05)$ were found with respect to such causes as: inadequate psychophysical state of an employee, lack of work supervision, and staying in a danger zone during tree felling or entering such a zone (Tab. 2). A higher significance of differences $(\mathrm{p}<0.01)$ were noted with respect to the improper use of firearms as the cause of accident.

More than $1 / 3$ of the examined forestry employees (37.5\%) aged 18-30 indicated the inadequate psychophysical state of an employee as the cause of occupational accidents, whereas among employees aged 31-50 and over 51, this opinion was shared by a more than twice lower percentage of respondents (approx. 16\%). Staying in the danger zone during tree felling or entering such a zone was perceived as the cause of accidents by $68.8 \%$ employees aged $18-30$, and $58.3 \%$ of those aged over 51 , while in the age group 31-50 this cause was reported by $49.3 \%$ of respondents. The lack of work supervision as the cause of accidents was indicated by $6.3 \%$ of employees in the age group $18-30,6 \%$ in the age group $31-50$, and $5.6 \%$ of employees aged over 51 .

Opinions concerning the causes of accidents among forestry employees at different workplaces were generally similar. Only 3 causes indicated by the respondents were perceived in a significantly different way by foresters, forestry rangers, and office employees (Tab. 2). Workplace was related with the indication of the following causes of accidents: psychophysical state of an employee, inadequate state of machinery, equipment, and vehicles, and lack of trainings in OSH. The opinion that the psychophysical state of an employee may be the cause of accident was shared mostly by forest rangers; nearly $1 / 3$ of forest rangers reported this cause of accidents. In the group of forest rangers, nearly twice as few respondents (16.9\%) mentioned the psychophysical state of an employee as the cause of an accident, whereas only every eleventh office employees shared this opinion (9.1\%). More than a half $(53.7 \%)$ of respondents employed at the workplace of forest ranger reported inadequate state of 
Table 2. Causes of accidents indicated by respondents according to type of workplace and period of employment

\begin{tabular}{|c|c|c|c|c|c|c|c|c|}
\hline & \multicolumn{4}{|c|}{ Workplace } & \multicolumn{4}{|c|}{ Period of employment } \\
\hline & $\begin{array}{l}\text { Forester } \\
\mathrm{N}=59\end{array}$ & $\begin{array}{l}\text { Forest ranger } \\
\qquad \mathrm{N}=52\end{array}$ & $\begin{array}{c}\text { Office } \\
\text { employee } \\
\mathrm{N}=22\end{array}$ & \multirow{2}{*}{$\begin{array}{c}\text { Level of } \\
\text { significanceof } \\
\text { differences }\end{array}$} & $\begin{array}{l}\text { Up to } \\
10 \text { years } \\
\mathrm{N}=50\end{array}$ & $\begin{array}{l}11-20 \\
\text { years } \\
\mathrm{N}=27\end{array}$ & $\begin{array}{l}21 \text { or } \\
\text { more } \\
\mathrm{N}=58\end{array}$ & \multirow{2}{*}{$\begin{array}{c}\text { Level of } \\
\text { significanceo } \\
\text { differences }\end{array}$} \\
\hline & \multicolumn{3}{|c|}{$\%$} & & \multicolumn{3}{|c|}{$\%$} & \\
\hline Lack of use of protective measures & 61.0 & 66.7 & 63.6 & & 64.0 & 81.5 & 55.2 & $\mathrm{p}<0,05$ \\
\hline Inadequate psychophysical state of employee & 16.9 & 31.5 & 9.1 & $\mathrm{p}<0.05$ & 28.0 & 7.4 & 22.4 & $n_{i}$ \\
\hline Inappropriate work organization & 15.3 & 27.8 & 27.3 & $\mathrm{n}_{\mathrm{i}}$ & 26.0 & 11.1 & 24.1 & $n_{i}$ \\
\hline Inappropriately prepared and organized workplace & 20.3 & 33.3 & 13.6 & $\mathrm{n}_{\mathrm{i}}$ & 24.0 & 18.5 & 27.6 & $n_{i}$ \\
\hline Improper, self-willed behaviour of the employee & 39.0 & 57.4 & 50.0 & $\mathrm{n}_{\mathrm{i}}$ & 54.0 & 29.6 & 51.7 & $\mathrm{p}<0.05$ \\
\hline Wild animals & 3.4 & 3.7 & 0.0 & $\mathrm{n}_{\mathrm{i}}$ & 2.0 & 7.4 & 1.7 & $\mathrm{n}_{\mathrm{i}}$ \\
\hline Physical phenomena (storms, blizzaeds) & 10.2 & 20.4 & 18.2 & $\mathrm{n}_{\mathrm{i}}$ & 26.0 & 11.1 & 8.6 & $\mathrm{n}_{\mathrm{i}}$ \\
\hline Chemical substances & 0.0 & 3.7 & 4.5 & $\mathrm{n}_{\mathrm{i}}$ & 4.0 & 3.7 & 0.0 & $\mathrm{n}_{\mathrm{i}}$ \\
\hline Bravado and neglecting hazards & 59.3 & 68.5 & 59.1 & $\mathrm{n}_{\mathrm{i}}$ & 58.0 & 74.1 & 62.1 & $\mathrm{n}_{\mathrm{i}}$ \\
\hline Being surprised by an unexpected event & 40.7 & 42.6 & 31.8 & $\mathrm{n}_{\mathrm{i}}$ & 32.0 & 33.3 & 50.0 & $\mathrm{n}_{\mathrm{i}}$ \\
\hline Lack of work supervision & 6.8 & 7.4 & 0.0 & $\mathrm{n}_{\mathrm{i}}$ & 2.0 & 18.5 & 3.4 & $p<0,05$ \\
\hline $\begin{array}{l}\text { Staying in a danger zone during tree felling or entering } \\
\text { such a zone }\end{array}$ & 49.2 & 57.4 & 72.7 & $\mathrm{n}_{\mathrm{i}}$ & 58.0 & 29.6 & 67.2 & $p<0.05$ \\
\hline Lack of trainings for employees in OSH & 1.7 & 11.1 & 0.0 & $p<0.05$ & 8.0 & 3.7 & 3.4 & $\mathrm{n}_{\mathrm{i}}$ \\
\hline Low level of training of employees in OSH & 3.4 & 1.9 & 0.0 & $\mathrm{n}_{\mathrm{i}}$ & 0.0 & 0.0 & 5.2 & $\mathrm{n}_{\mathrm{i}}$ \\
\hline Non-availability of OSH instructions & 0.0 & 3.7 & 0.0 & $\mathrm{n}_{\mathrm{i}}$ & 0.0 & 3.7 & 1.7 & $n_{i}$ \\
\hline $\begin{array}{l}\text { Lack of observance of regulations concerning especially } \\
\text { dangerous work activities }\end{array}$ & 22.0 & 42.6 & 31.8 & $\mathrm{n}_{\mathrm{i}}$ & 38.0 & 14.8 & 34.5 & $\mathrm{n}_{\mathrm{i}}$ \\
\hline
\end{tabular}

$n_{i}$-statistically insignificant difference

Table 3. Causes of accidents indicated by respondents according to age and education level

\begin{tabular}{|c|c|c|c|c|c|c|c|}
\hline & \multicolumn{3}{|c|}{ Education } & \multicolumn{4}{|c|}{ Age } \\
\hline & $\begin{array}{c}\text { Secondary } \\
\text { school or lower } \\
\mathrm{N}=75\end{array}$ & $\begin{array}{l}\text { Higher } \\
\mathrm{N}=60\end{array}$ & \multirow{2}{*}{$\begin{array}{c}\text { Level of } \\
\text { significanceof } \\
\text { differences }\end{array}$} & $\begin{array}{l}18-30 \text { years } \\
\mathrm{N}=32\end{array}$ & $\begin{array}{l}31-50 \text { years } \\
N=63\end{array}$ & $\begin{array}{l}51 \text { or over } \\
\mathrm{N}=36\end{array}$ & \multirow{2}{*}{$\begin{array}{c}\text { Level of } \\
\text { significanceof } \\
\text { differences }\end{array}$} \\
\hline & \multicolumn{2}{|l|}{$\%$} & & & $\%$ & & \\
\hline Lack of use of protective measures & 58.7 & 70.0 & $\mathrm{n}_{\mathrm{i}}$ & 68.8 & 62.7 & 61.1 & $\mathrm{n}_{\mathrm{i}}$ \\
\hline Inadequate psychophysical state of employee & 29.3 & 11.7 & $\mathrm{p}<0.05$ & 37.5 & 16.4 & 16.7 & $\mathrm{p}<0.05$ \\
\hline Inappropriate work organization & 18.7 & 26.7 & $\mathrm{n}_{\mathrm{i}}$ & 31.3 & 20.9 & 16.7 & $\mathrm{n}_{\mathrm{i}}$ \\
\hline Inappropriately prepared and organized workplace & 25.3 & 23.3 & $\mathrm{~N}_{\mathrm{i}}$ & 34.4 & 22.4 & 19.4 & $\mathrm{n}_{\mathrm{i}}$ \\
\hline Improper, self-willed behaviour of the employee & 53.3 & 41.7 & $\mathrm{n}_{\mathrm{i}}$ & 56.3 & 43.3 & 50.0 & $\mathrm{n}_{\mathrm{i}}$ \\
\hline Wild animals & 1.3 & 5.0 & $\mathrm{n}_{\mathrm{i}}$ & 3.1 & 4.5 & 0.0 & $\mathrm{n}_{\mathrm{i}}$ \\
\hline Physical phenomena (storms, blizzards) & 17.3 & 13.3 & $\mathrm{n}_{\mathrm{i}}$ & 21.9 & 17.9 & 5.6 & $\mathrm{n}_{\mathrm{i}}$ \\
\hline Chemical substances & 0.0 & 5.0 & $\mathrm{n}_{\mathrm{i}}$ & 0.0 & 4.5 & 0.0 & $\mathrm{n}_{\mathrm{i}}$ \\
\hline Inadequate state of machinery, equipment, and vehicles & 41.3 & 30.0 & $\mathrm{n}_{\mathrm{i}}$ & 62.5 & 26.9 & 30.6 & $\mathrm{n}_{\mathrm{i}}$ \\
\hline Bravado and neglecting hazards & 58.7 & 68.3 & $\mathrm{n}_{\mathrm{i}}$ & 56.3 & 71.6 & 52.8 & $\mathrm{n}_{\mathrm{i}}$ \\
\hline Being surprised by an unexpected event & 40.0 & 40.0 & $\mathrm{n}_{\mathrm{i}}$ & 31.3 & 43.3 & 41.7 & $\mathrm{n}_{\mathrm{i}}$ \\
\hline Lack of work supervision & 2.7 & 10.0 & $\mathrm{n}_{\mathrm{i}}$ & 6.3 & 6.0 & 5.6 & $\mathrm{p}<0.05$ \\
\hline $\begin{array}{l}\text { Staying in a danger zone during tree felling or entering } \\
\text { such a zone }\end{array}$ & 54.7 & 58.3 & $\mathrm{n}_{\mathrm{i}}$ & 68.8 & 49.3 & 58.3 & $\mathrm{p}<0.05$ \\
\hline Lack of trainings for employees in OSH & 8.0 & 1.7 & $\mathrm{n}_{\mathrm{i}}$ & 12.5 & 3.0 & 2.8 & $\mathrm{n}_{\mathrm{i}}$ \\
\hline Low level of training of employees in $\mathrm{OSH}$ & 2.7 & 1.7 & $\mathrm{n}_{\mathrm{i}}$ & 0.0 & 1.5 & 5.6 & $n_{i}$ \\
\hline Non-availability of OSH instructions & 1.3 & 1.7 & $\mathrm{n}_{\mathrm{i}}$ & 0.0 & 3.0 & 0.0 & $\mathrm{n}_{\mathrm{i}}$ \\
\hline $\begin{array}{l}\text { Lack of observance of regulations concerning especially } \\
\text { dangerous work activities }\end{array}$ & 33.3 & 30.0 & $\mathrm{n}_{\mathrm{i}}$ & 40.6 & 32.8 & 22.2 & $\mathrm{n}_{\mathrm{i}}$ \\
\hline
\end{tabular}

$\mathrm{n}_{\mathrm{i}}$ - statistically insignificant difference 
machinery, equipment, and vehicles as the cause of accidents. In turn, among foresters and office employees, the percentage of persons indicating this cause of accidents was more than twice as low (25.4\% of foresters and $22.7 \%$ of office employees). The same level of significance of the differences was observed for the cause of accidents associated with the lack of training of employees in OSH. This cause was most frequently mentioned by forest rangers (11.1\%), while among foresters this percentage was only $1.7 \%$, and none of the office employees reported this cause.

An interesting result of the analyses performed is the lack of relationship between opinions concerning the causes of accidents in forestry and the respondents' education. Differences were found with respect to only one per 18 causes of accidents at work mentioned according to respondents' education level (Tab. 3). A significant difference on the level $\mathrm{p}<0.05$ was observed concerning the psychophysical state of an employee; this cause was indicated by $29.3 \%$ employees, with secondary school or university education, and by a nearly three times lower percentage of those with university education (11.7\%).

Index of workers' concern about safety at work. The analyses performed also demonstrate that the indication by the respondents of specified causes of accidents is connected with their use of protective measures, expressed by the index of concern about OSH (Tab. 4). Analysis of opinions concerning the causes of accidents in forestry in the subgroups selected according to the level of concern about OSH, shows that persons characterized by a high level of concern about OSH more frequently than others become aware of accident risk and indicate its causes. Statistically significant differences were observed with respect to 7 causes of incidents mentioned.

The highest differences (on the level $\mathrm{p}<0.001$ ) were found concerning the opinion that causes of accidents are associated with inappropriate organization of work. This cause was reported by $45.8 \%$ of respondents with a high level of concern about safety, and a 3 times lower percentage (15.9\%) of those who showed a low level of concern about OSH. In the group of respondents with a mediocre level of concern about OSH, only one (2.3\%) indicated inappropriate work organization as the cause of accidents.

In groups with a different level of concern about OSH, there also occurred statistically significant differences (on the level $\mathrm{p}<0.01$ ) in the perception of causes of accidents connected with the so-called human factor, i.e.: inadequate psychophysical state of an employee; inappropriate preparation and organization of the workplace; improper self-willed behaviour of the worker, and being surprised by an unexpected event. The psychophysical state of an employee was mentioned by $37.5 \%$ of respondents who, to the highest degree, were concerned about work safety. Being surprised by an unexpected event was reported by $58.3 \%$ of employees who were most concerned about safety, whereas in the group of respondents whose concern was on a low level - 34.1\%, and in the group of employees showing a mediocre level of the index $-25.6 \%$.

The lowest statistically significant differences $(\mathrm{p}<0.05)$ in the evaluation of the causes of accidents by the respondents with different levels of concern about safety at the workplace, were observed concerning such causes of accidents as: lack of use of protection measures, lack of supervision, lack of observance of regulations concerning especially dangerous work activities, and physical phenomena. Nearly $80 \%$ of respondents who were concerned about OSH on a mediocre level as the cause of accidents, considered the lack of use of protective measures, followed by $60.4 \%$ of those who were most concerned about OSH, and $52.3 \%$ of employees showing a low level of concern about OSH. The highest percentage of respondents who, as the cause of accidents, indicated lack of observance of the regulations concerning especially dangerous work activities were those who demonstrated a high level of concern about OSH (45.8\%). The percentages of respondents who were concerned about OSH on a low (25\%) and mediocre level (23.3\%) were lower.

Lack of work supervision was indicated as the cause of accidents by $12.5 \%$ of respondents who showed a high level of concern about OSH, and $4.5 \%$ of those with a low index of concern about OSH indicated this cause of occupational accidents. No one from the group of employees who were concerned about OSH on a mediocre level, mentioned this cause of occupational accidents.

The risk of occurrence of an accident due to physical phenomena, e.g. storm, was reported by $27.1 \%$ of respondents who showed a high level of concern about safety, a more than twice lower percentage of persons concerned about safety on a low level (11\%), and a 4 times lower percentage of respondents concerned about OSH on a mediocre level (7\%).

In each subgroup selected according to the level of concern about OSH, it may be determined which from among the causes of accidents create the greatest risk, as reported by a higher percentage of respondents. In each group, 5 causes were taken into consideration which, in a given group, obtained the highest percentage of indications (Tab. 5). Considering this criterion, it was found that among employees with a low level of concern about OSH the source of the greatest accident risk is staying in a danger zone during tree felling or entering such a zone. This cause is considerably less important in the group of employees concerned about OSH to mediocre and high levels, occupying the third position according to the percentage of indications. Forestry employees with a mediocre level of concern about OSH more often reported that the cause of accidents is the lack of use of protective measures. The smallest attention to this cause is paid by employees who showed high concern about the use of such protective measures $\left(4^{\text {th }}\right.$ position according o the percentage of indications). In this group of forestry employees, the most often expressed opinion was that the source of accident risk is the employee himself - bravado and neglecting hazards (highest percentage of indications), as well as improper, selfwilled behaviour of the employee ( $2^{\text {nd }}$ position according to the frequency of indications). Bravado and neglecting hazards was also an important cause of accidents in the group of employees showing mediocre and low level of concern about OSH ( $2^{\text {nd }}$ position in both groups). The list of the 5 most frequently mentioned causes of accidents in the group of forestry employees who showed a mediocre level of concern about $\mathrm{OSH}$, included the inadequate state of machinery, equipment, and vehicles ( $4^{\text {th }}$ position), whereas in the remaining groups this cause of accidents did not occur among the 5 which were most often mentioned. 
Table 4. Causes of accidents indicated by respondents according to the level of concern about OSH (\%).

\begin{tabular}{|c|c|c|c|c|}
\hline & \multicolumn{3}{|c|}{ Low level of OSH } & \multirow{2}{*}{$\begin{array}{l}\text { Level of significance of } \\
\text { differences }\end{array}$} \\
\hline & $\begin{array}{l}\text { Low } \\
\mathrm{N}=44\end{array}$ & $\begin{array}{l}\text { Mediocre } \\
\mathrm{N}=43\end{array}$ & $\begin{array}{l}\text { High } \\
\mathrm{N}=48\end{array}$ & \\
\hline Inadequate psychophysical state of employee & 11.4 & 14.0 & 37.5 & $\mathrm{p}<0.01$ \\
\hline Inappropriate work organization & 15.9 & 2.3 & 45.8 & $\mathrm{p}<0.001$ \\
\hline Improper, self-willed behaviour of the employee & 50.0 & 27.9 & 64.6 & $\mathrm{p}<0.01$ \\
\hline Wild animals & 2.3 & 0.0 & 6.3 & $\mathrm{n}_{\mathrm{i}}$ \\
\hline Physical phenomena (storms, blizzards) & 11.4 & 7.0 & 27.1 & $\mathrm{p}<0.05$ \\
\hline Chemical substances & 0.0 & 2.3 & 4.2 & $\mathrm{n}_{\mathrm{i}}$ \\
\hline Improper use of firearms & 4.5 & 9.3 & 4.2 & $\mathrm{n}_{\mathrm{i}}$ \\
\hline Inadequate state of machinery, equipment, and vehicles & 22.7 & 39.5 & 45.8 & $n_{i}$ \\
\hline Bravado and neglecting hazards & 54.5 & 58.1 & 75.0 & $\mathrm{n}_{\mathrm{i}}$ \\
\hline Being surprised by an unexpected event & 34.1 & 25.6 & 58.3 & $\mathrm{p}<0.01$ \\
\hline Lack of work supervision & 4.5 & 0.0 & 12.5 & $\mathrm{p}<0.05$ \\
\hline Staying in the danger zone during tree felling or entering such a zone & 59.1 & 46.5 & 62.5 & $n_{i}$ \\
\hline Lack of trainings for employees in OSH & 0.0 & 0.0 & 14.6 & - \\
\hline Low level of training of employees in OSH & 0.0 & 0.0 & 6.3 & - \\
\hline Non-availability of OSH instructions & 0.0 & 0.0 & 4.2 & - \\
\hline Lack of observance of regulations concerning especially dangerous jobs & 25.0 & 23.3 & 45.8 & $\mathrm{p}<0.05$ \\
\hline
\end{tabular}

Table 5. Most frequently indicated causes of accidents at work according to the level of concern about OSH

\begin{tabular}{|c|c|c|c|}
\hline \multirow{2}{*}{$\begin{array}{l}\text { Position determined } \\
\text { by the percentage of } \\
\text { indications }\end{array}$} & \multicolumn{3}{|c|}{ Level of concern bout OSH } \\
\hline & Low & Mediocre & High \\
\hline 1 & $\begin{array}{l}\text { Staying in a danger zone during tree felling or } \\
\text { entering such a zone }\end{array}$ & Lack of use of protective measures & Bravado and neglecting hazards \\
\hline 2 & Bravado and neglecting hazards & Bravado and neglecting hazards & $\begin{array}{l}\text { Improper, self-willed behaviour of the } \\
\text { employee }\end{array}$ \\
\hline 4 & $\begin{array}{l}\text { Improper, self-willed behaviour of an } \\
\text { nemployee }\end{array}$ & $\begin{array}{l}\text { Inadequate state of machinery, equipment, } \\
\text { and vehicles }\end{array}$ & Lack of use of protective measures \\
\hline 5 & Being surprised by an unexpected event & $\begin{array}{l}\text { Improper, self-willed behaviour of an } \\
\text { employee }\end{array}$ & Being surprised by an unexpected event \\
\hline
\end{tabular}

\section{DISCUSSION}

The results of the study demonstrate that the most frequently indicated causes of occupational accidents in forestry by workers were factors related with human behaviour. These were: lack of use of protective measures, bravado and neglecting hazards, staying in a danger zone during tree felling or entering such a zone, and improper, self-willed behaviour of the employee. According to accident statistics by the GUS, the most frequent cause of occupational accidents in forestry during 2010-2017 was improper behaviour of the employee [14].

A study conducted by Ghaffariyan [16] among forestry employees in Australia showed that the majority of accidents took place during timber harvesting (37\%) and forest management $(30.2 \%)$, and the main causes of accidents for various types of activities were primarily human error, such as an operator's mistake, lack of personal protection equipment, assuming an improper body position, improper techniques and work methods. These accidents included work activities associated with timber harvesting, during which the behaviour of employees and the way of performing work exert an effect on their safety. Work activities connected with timber harvesting in Polish forests are practically performed by the employees of private services companies. This group of employees is especially exposed to accident risk on the part of machines used for wood cutting and processing. Supervision of other tasks connected with the maintenance of forests are performed by employees of the State Forests (mainly foresters and forest rangers). It was confirmed that work activities associated with supervision may also be dangerous. Thus, safety while performing all types of activities performed in forestry depends on the so-called human factor, which was indicated by the examined employees of the State Forests.

Accident statistics by the GUS demonstrate that employees with a long period of employment ( $>16$ years) most often suffer from accidents, as well as those who are newlyemployed whose period of employment does not exceed 
one year [14]. Young employees do not possess the skill for recognizing hazards, which may result from an insufficient level of training and supervision by their superiors. It should be mentioned that the number of victims of occupational accidents decreases, together with an increase in the duration of employment. This evidences the skills of making the right decisions due to the acquisition of greater occupational experience and knowledge, strengthened during the subsequent, periodical OSH trainings.

The results of the study show that the greatest differences in the perception of hazards among the examined forestry employees were observed according to the period of employment and age. Improper, self-willed behaviour of the worker as the cause of accidents was similarly perceived by employees with the shortest (up to 10 years) and the longest (more than 21 years) period of employment. In turn, the lack of use of protective measures as the cause of occupational accidents was reported by the largest group (81.5\%) of forestry employees with a mediocre period of employment (11-20 years), and the longest period of employment (more than 21 years) - this cause was indicated by $55.2 \%$ of respondents. Thus, employees with the longest period of employment did not pay attention to the use of protective equipment. The period of employment also exerted an effect on the culture of work safety, which was confirmed by Nowicki et al. [19].

Statistically significant differences were also observed according to age. More than $1 / 3$ of the examined forestry employees aged 18-30 reported an inadequate psychophysical state of an employee as the cause of occupational accidents, whereas among the remaining age groups, this opinion was shared by a twice lower percentage of respondents. According to data by the GUS, the largest number of people aged 30-39 were the victims to accidents [14]. This may be due to the fact that they constitute the largest group of employees [20], or it may be a sign of routine or of becoming acquainted with employees and getting used to threats which, in turn, provokes them to risky behaviors.

Opinions concerning the causes of accidents among forestry workers employed at various workplaces were generally similar. Only 3 causes of accidents indicated by the respondents (inadequate psychophysical state of an employee, inadequate state of machinery, equipment, and vehicles, and lack of trainings in $\mathrm{OSH}$ ) were perceived in a significantly different way by foresters, forestry rangers and office employees. In the study by Grzywiński et al. [1], the workplace occupied exerted a definite effect on the number of accidents occurring. The largest number of victims occurred in the position of labourer, while the lowest number of events were noted among office employees. At the workplaces of labourers, the most frequent accidents were suffered by lumberjacks - operators of chainsaw and forestry labourers. Among the forestry administration, the largest number of accidents were observed at the workplaces of foresters and forest rangers [9].

Studies concerning occupational accidents described in international literature primarily concern all work activities associated with timber harvesting, timber processing and transport. Laschi et al. [21] reported that logging and forestry processing are the most dangerous activities in forestry, whereas in forestry operations, injuries most often concerned the hands and palms of the hands.

The human factor plays an important role in the occurrence of accidents. The variables connected with the risk of injuries among persons engaged in timber processing include, among others: physical load, operation of machinery, lack of breaks at work, lack of trainings, lack of lockout/tagout software, short period of employment, and male gender [22]. These factors may increase psychological stress, muscular and locomotor system load, leading eventually to musculoskeletal disorders and accidents at work [23].

Despite the fact that in many countries a decrease is observed in the number of fatal accidents in forestry, in Turkey it still remains on a high level. According to Melemez [24], this may result from the employment of seasonal workers, lack of the use of safety measures, and lack of trainings in the area of safety.

Polish statistics by the GUS do not cover sole proprietorship, which are the main entities engaged in timber harvesting. However, it may be presumed that the accidents they suffer are mainly connected with behaviour while operating machines. A study conducted in Sweden among self-employed forestry employees did not show any significant relationship between the level of production, age, use of protective measures, and the number and type of occupational accidents. Accidents were caused by unforeseen interactions on the part of falling trees/branches, or the equipment used. Nevertheless, 50\% of accident victims or participants reported that during the accident or event they did not fully use protection measures. In the opinion of the researchers, better planning of the process of tree felling may be the key to reducing the number of accidents at work [25].

The performed analyses also shows that the indication by forestry employees of specified causes of accidents is associated with the scope of their using protective measures, as expressed by the index of concern about OSH. Employees characterized by a high level of concern about occupational safety more often than the reminder were aware of accident risk, indicating specified causes of accidents. Employees with a high level of concern about safety among the causes of accidents, most often reported bravado and neglecting hazards and improper, self-willed behaviour of the employee. This is reflected in the accident statistics. In turn, among employees with a low level of concern about OSH, the source of the highest accident risk was staying in a danger zone during tree felling or entering such a zone.

Foresters paid the greatest attention to the cause resulting from the use of protective measures, and showed great care about the use of such protections. In this group of foresters, the opinion most frequently expressed was the conviction that the source of accident risk is the worker himself - bravado and neglecting hazards (highest percentage of indications), and improper, self-willed behaviour of the employee. Bravado and neglecting hazards is also an important cause of accidents in the groups of employees who are concerned about OSH to a mediocre and low degree.

In the literature, there are many reports concerning forestry in Turkey, where the forested area occupies about one-fifth of the territory of the country. Yoshimura and Acar [26] demonstrated that among 113 seasonal workers, a very large group of respondents (as many as 73\%) did not use any personal protection measures, while the remaining $27 \%$ used protective gloves, footwear, goggles, and hearing protection [26]. Similar results were presented by Enez et al. [27]. Different results were obtained by Gedik and Korkut [28], who found that $77.7 \%$ of employees, in order to provide safety, use protective measures at the workplace, mainly 
gloves, masks, goggles, and helmets. In this study, it was also found that the older and more experienced the employees, the more rarely they used protective measures.

\section{CONCLUSIONS}

The forestry employees in the study demonstrated a high awareness and knowledge concerning the causes of occupational accidents in forestry. They most often indicated the causes of accidents as improper, self-willed behaviour of the employee, bravado and neglecting hazards and lack of use of protective measures, which dominate in accident statistics.

Considering the investigated variables, the greatest differences in the way of perceiving hazards by the examined forestry employees were observed according to the period of employment and age. Opinions concerning the causes of accidents among forestry employees at various workplaces were generally similar. No relationship was found between opinions concerning the causes of accidents in forestry and education level of the respondents.

The analyses performed also showed that there is a relationship between indication by forestry employees of specified causes of accidents and the scope of their using protective measures, expressed by the index of concern about OSH. Respondents who were characterized by a high level of concern about work safety, more often than others were aware of accident risk, and reported specified causes.

\section{REFERENCES}

1. Pecyna A, Buczaj A, Lachowski S, Choina P, Goździewska M, Galińska EM. Occupational hazards in opinions of forestry employees in Poland. Ann Agric Environ Med. doi: 10.26444/aaem/106246

2. Fibiger W. Ochrona zdrowia pracowników leśnictwa. Warszawa 1976 , PZWL. (in Polish)

3. Fibiger W, Jasnos P, Kanecka M, Walicki R. Analiza ciężkich wypadków przy pracy w lesie. Pr Inst Bad Leśn. 1973; 440: 3-23. (in Polish)

4. Jabłoński K. Analiza wypadkowości w leśnictwie w latach 1990-1994 na przykładzie Regionalnej Dyrekcji Lasów Państwowych w Poznaniu. Zastos Ergon. 1996; (2-3): 131-138. (in Polish)

5. Józefaciuk J. Nauka o pracy i ochrona pracy w leśnictwie. Warszawa 1970, Wyd. SGGW. (in Polish)

6. Kubiak M. Struktura wypadków przy pracy w gospodarstwie leśnym i dynamika ich wzrostu. Sylwan 1985; 129(12): 13-21. (in Polish)

7. Muszyński Z. Ergonomia a wypadkowość w leśnictwie. Zastos Ergon. 1996; (2-3): 125-129. (in Polish)

8. Olszewski A. Aktualne tendencje w statystyce wypadków przy pracach leśnych. Głos Lasu 1998; (1): 30-31. (in Polish)

9. Grzywiński W, Sawa L, Nowik A, Nowicki G. Struktura wypadków przy pracy w Regionalnej Dyrekcji Lasów Państwowych w Szczecinku w latach 1990-2009. Sylwan 2013; 157(6): 403-411. (in Polish)
10. Nowacka WŁ, Moskalik T. Negatywne skutki pracy w leśnictwie ze szczególnym uwzględnieniem pozyskiwania drewna. Forestry Letters 2013; (105): 85-93. (in Polish)

11. Burzyńska-Jędrzejczak G, Kaźmierczak K. Struktura wypadków przy pozyskaniu drewna w regionalnych dyrekcjach Lasów Państwowych w latach 2011-2015. Acta Sci. Pol. Silv. Colendar. Ratio Ind. Lignar. 2017; 16(3): 177-187. (in Polish)

12. Grzywiński W, Kapelan A, Wiekiera J. Analysis of accident rate in the Regional Directorate of the State Forests in Poznań in the years 1995-2007. In: Sowa JM, Barszcz A, Szewczyk G (ed.). Technology and ergonomics in the service of modern forestry. Kraków, 2011. Wyd. UR, pp. 55-71.

13. Burzyńska-Jędrzejczak G, Kaźmierczak K. Wypadkowość w regionalnych dyrekcjach Lasów Państwowych w latach 2006-2015. Przegląd leśniczy 2017; (4): 7-9.

14. Rocznik statystyczny leśnictwa 2018. Główny Urząd Statystyczny, Warszawa 2018. ISSN 2657-3199. https://stat.gov.pl/obszarytematyczne/roczniki-statystyczne/roczniki-statystyczne/rocznikstatystyczny-lesnictwa-2018,13,1.html. (access: 27.03.2019)

15. Kancelaria Sejmu, Biuro Komisji Sejmowych. Biuletyn z 22 posiedzenia Rady Ochrony Pracy (X kad.) w dniu 22 maja 2017 r., pp. 9-12, 23 https:// jbc.bj.uj.edu.pl/Content/381103/PDF/NDIGOC018495_2017_022.pdf (access: 10.06.2019), (in Polish)

16. Ghaffariyan MR. Analysis of forestry work accidents in five Australian forest companies for the period 2004 to 2014 Journal of Forest Science 2016; 62(12): 545-552 doi: 10.17221/80/2016-JFS

17. Gellerstedt S. Ergonomic guidelines for forest machines. Proceedings of the Human Factors and Ergonomics Society Annual Meeting 2000; (44): 477-480.

18. Synwoldt U, Gellerstedt S. Ergonomic initiatives for machine operators by the Swedish logging industry. Appl Ergon. 2003; (34): 149-156.

19. Nowacki K, Łakomy K, Lis T. Staż pracy a kultura bezpieczeństwa. http://www.ptzp.org.pl/files/konferencje/kzz/artyk_pdf_2016/T2/ t2_0448.pdf (access: 10.06.2019), (in Polish)

20. Monitoring Rynku Pracy - Informacja o rynku pracy w czwartym kwartale 2018 roku. https://stat.gov.pl/obszary-tematyczne/rynekpracy/pracujacy-bezrobotni-bierni-zawodowo-wg-bael/monitoringrynku-pracy-informacja-o-rynku-pracy-w-czwartym-kwartale-2018roku,12,36.html (access: 27.03.2019), (in Polish)

21. Laschi A, Marchi E, Foderi C, Neri F. Identifying causes, dynamics and consequences of work accidents in forest operations in an alpine context. Safety Science 2016; (89): 28-35, https://doi.org/10.1016/j. ssci.2016.05.017 (access: 10.06.2019)

22. Holcroft C, Punnett L. Work environment risk factors for injuries in wood processing. J Saf Res. 2009; (40): 247-255.

23. Gallis C. Work-related prevalence of musculoskeletal symptoms among Greek forest workers. Int J Indust Ergon. 2006; (36): 731-736.

24. Melemez K. Risk factor analysis of fatal forest harvesting accidents: A case study in Turkey. Safety Science. 2015; (79): 369-378. https://doi. org/10.1016/j.ssci.2015.07.004

25. Neely G, Wilhelmson E. Self-reported incidents, accidents, and use of protective gear among small-scale forestry workers in Sweden. Saf Sci. 2006; (44): 723-732.

26. Yoshimura T, Acar H. Occupational safety and health conditions of forestry workers in Turkey. J Forest Res 2004; 9(3): 225-232. DOI: 10.1007/s10310-004-0078-y

27. Enez K, Topbas M, Acar H. An evaluation of the occupational accidents among logging workers within the boundaries of Trabzon Forestry Directorate, Turkey. Int J Industrial Ergon. 2014; 44(5): 621-628, https:// doi.org/10.1016/j.ergon.2014.07.002

28. Gedik T, Korkut DS. A research on work accidents in forest products industry in Duzce. Int J Physical Sci. 2011; 6(30): 7065-7072. DOI: 10.5897/IJPS11.1007

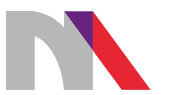

Ministry of Science and Higher Education

Republic of Poland

Generation of the DOI (Digital Object Identifier) - task financed under the agreement No. 618/P-DUN/2019 by the Minister of Science and Higher Education 